\title{
Estimation of the residential radon levels and the annual effective dose in dwellings of Shiraz, Iran, in 2015
}

Maryam Yarahmadi ${ }^{1}$, Abbas Shahsavani ${ }^{2,3}$, Mohammad Hassan Mahmoudian ${ }^{4}$, Narges Shamsedini ${ }^{5}$, Noushin Rastkari $^{6}$, Majid Kermani ${ }^{7}$

${ }^{1}$ Environmental and Occupational Health Center, Ministry of Health and Medical Education, Tehran, Iran

${ }^{2}$ Environmental and Occupational Hazards Control Research Center, Shahid Beheshti University of Medical Science, Tehran, Iran

${ }^{3}$ Ph.D., Assistant Professor, Department of Environmental Health Engineering, School of Public Health, Shahid Beheshti University of Medical Science, Tehran, Iran

${ }^{4}$ Research Center for Environmental Pollutants, Qom University of Medical Sciences, Qom, Iran

${ }^{5}$ Department of Environmental Health Engineering, School of Health, Student Research Committee, Shiraz University of Medical Sciences, Shiraz, Iran

${ }^{6}$ Center for Air Pollution Research (CAPR), Institute for Environmental Research (IER), Tehran University of Medical Sciences, Tehran, Iran

${ }^{7}$ Department of Environmental Health Engineering, School of Public Health, Iran University of Medical Sciences, Tehran, Iran

\section{Type of article: Original}

\begin{abstract}
Introduction: Radon is the second most important cause of lung cancer after smoking. Thus, the determination of indoor radon concentrations in dwellings and workplaces is an important public health concern. The purpose of this research was to measure the concentration of radon gas in residential homes and public places in the city of Shiraz and its relationship with the type and age of the buildings as well as the type of materials used to construct the building (brick, block). We also determined the radon dosages that occupants of the building would receive.

Methods: The present study is a descriptive-analytical and cross-sectional research that was conducted on the building's indoor air in the city of Shiraz in 2015. Using geographic information system (GIS) software and a spatial sampling cell with an area of 25 square kilometers, 200 points were selected. In this study, we used passive diffusive samplers as Solid State Nuclear Track Detector (SSNTD) CR-39 polycarbonate films for three months in the winter. Sampling was conducted in accordance with the U.S. Environmental Protection Agency's protocol. We determined the concentrations of radon gas at the time of sampling, and calibration factors were determined. The data were analyzed by IBM-SPSS, version 20, descriptive statistics, Kruskal-Wallis, and MannWhitney tests.

Results: This study showed that the average radon concentration was $57.6 \pm 33.06 \mathrm{~Bq} / \mathrm{m}^{3}$ in residential dwellings. The average effective dose was $1.45 \mathrm{mSv} / \mathrm{y}$. The concentration of radon in $5.4 \%$ of the houses was found to be greater than $100 \mathrm{~Bq} / \mathrm{m}^{3}$, which is above the level allowed by the World Health Organization (WHO).

Conclusion: Since radon is the second leading cause of lung cancer, it seems necessary to increase the public's awareness of this issue and to take action to reduce radon in homes when the concentrations are above the WHO's guideline.

Keywords: Indoor radon, CR-39, Lung cancer, Shiraz, ICRP
\end{abstract}

\section{Corresponding author:}

Assistant Professor Dr. Abbas Shahsavani, Environmental and Occupational Hazards Control Research Center, Shahid Beheshti University of Medical Science, Tehran, Iran.

Tel: +98.2122432040, Email: ashahsavani@sbmu.ac.ir

Received: January 09, 2016, Accepted: April 09, 2016, Published: June 2016

iThenticate screening: April 09, 2016, English editing: April 30, 2016, Quality control: June 04, 2016

(C) 2016 The Authors. This is an open access article under the terms of the Creative Commons Attribution-NonCommercialNoDerivs License, which permits use and distribution in any medium, provided the original work is properly cited, the use is non-commercial and no modifications or adaptations are made. 


\section{Introduction}

Radon is a natural radioactive, odorless, colorless, tasteless gas that is undetectable by the senses. It is chemically inert, and its density is eight times that of air. It is naturally emitted from rocks and soil as a product of the decay of radium 226, which has a half-life of 3.82 days $(1,2)$. The most important isotope of radon is radon 222, which tends to accumulate in closed spaces and enters the lungs by breathing. It damages the lung tissue after positioning itself in the alveoli and producing alpha particles (3). In addition, it also exposes the internal parts of the body to the radiation. It may cause emphysema and fibrosis, and it ultimately increases the likelihood of the occurrence of lung cancer $(4,5)$. When there is long-term contact with radon, it definitely leads to lung cancer, and the symptoms appear years later $(4,6)$. Almost $11 \%$ of the lung cancer deaths in smokers and $23 \%$ of the lung cancer deaths in non-smokers are attributable to radon (6). Radon is known to be the second largest factor of lung cancer after smoking, and its role as the first cause of cancer in non-smokers has been proven $(7,8)$. In 1988, radon was classified as a human carcinogenic agent by the International Agency for Research on Cancer (IARC) $(5,6)$. The cancer risk in areas containing $148 \mathrm{~Bq} / \mathrm{m}^{3}$ radon is almost 1 in $100(6)$. The number of lung cancer cases attributable to radon exposure in the United States was estimated at 21,000 individuals, which is equivalent to $10-15 \%$ of lung cancer deaths (9). Also, the percentage of lung cancer deaths attributable to radon is $7.8 \%$ in Canada, $5 \%$ in Germany, $8.3 \%$ in Switzerland, and 5-12\% in France (6). The relationship between radon gas and other types of cancer, such as leukemia, melanoma, and stomach cancer, also has been established $(10,11)$. The average annual amount of human exposure (effective dose) to all natural radioactive sources is estimated at $2.4 \mathrm{mSv}$, and about $52 \%$ of this exposure is caused by the inhalation of radon gas (2). The radon concentration in outside air is usually less than $15 \mathrm{~Bq} / \mathrm{m}^{3}$, and this is due to the high volume and constant motion of the air. It is far higher in closed spaces, such as the indoor air in buildings, which has been reported to be around 37,000 to $111,000 \mathrm{~Bq} / \mathrm{m}^{3}$ (6). Radon enters the building through floor seams and gaps, walls, and pipelines below the building, fittings' seams, wall pits, concentrated radon in the basement, floor fractures, water and sewage pipes, and the groundwater used in residential buildings (5). The maximum permissible limit of radon concentration in the indoor air recommended by the U.S. Environmental Protection Agency (USEPA) is $148 \mathrm{~Bq} / \mathrm{m}^{3}$ (9), however, the WHO recommends $100 \mathrm{~Bq} / \mathrm{m}^{3}$ as the permissible limit of radon concentration in the indoor air. During a study by WHO in 36 countries, the reference level of radon for the existing buildings was between $200-400 \mathrm{~Bq} / \mathrm{m}^{3}(6)$. The concentrations of radon gas in the indoor air of residential buildings in Finland (12), Cyprus (13), Russia (14), Germany (15), Romania (16), Spain (16), Vietnam (17), India (18), Turkey (19), Saudi Arabia (20), Babolsar (21), Gonabad (21), Yazd (22), and Tehran (Ekbatan Housing Complex) (23) were found to be 155, 6.2, 102.8, 52, 400, 2650, 366, 7-100, $46 \pm 26,9-98,130$, $35 \pm 83,79 \pm 3,137.36 \pm 149.5$, and $18.4 \mathrm{~Bq} / \mathrm{m}^{3}$, respectively. Based on extensive studies at Ramsar region in Iran, the annual effective dose for an individual was reported as $2.48-71.74 \mathrm{mSv} / \mathrm{y}$, which is much more than the dose received from natural sources (23). In the only study conducted in Shiraz (2009-2010), the concentration of radon gas in a number of houses was over $200 \mathrm{~Bq} / \mathrm{m}^{3}$, which requires more investigations of radon gas in this city (24). Regarding the internal exposure problem and the increasing rates of lung cancer caused by exposure to this radiation, it is important to measure the concentration of radon gas in order to calculate the actual radiation dose received from radon (25). The purpose of this research was to measure the concentrations of radon gas in residential homes and public places in the City of Shiraz and their relationship with the type of buildings (residential, public place), the age of the buildings (old, newly-built), the type of materials used in constructing the buildings (brick, cement block), floor and place of sampling, the type of flooring used in the building, and also to determine the dosage received from it.

\section{Material and Methods}

\subsection{Research design and setting}

This study was a descriptive-analytical and cross-sectional research study that was conducted on buildings' indoor air in the City of Shiraz in 2015 . The area is 1480 to $1670 \mathrm{~m}$ above sea level, and it is located in southwestern Iran (26). Its surface area is $1268 \mathrm{~km}^{2}$ with a population of $1,700,687$ (27). There are 485,910 households in the city. The average annual temperature is $18{ }^{\circ} \mathrm{C}$, and the average temperature in July (the hottest month of the year) is $30{ }^{\circ} \mathrm{C}$. The average in January (the coldest month of the year) is $5{ }^{\circ} \mathrm{C}(26)$.

\subsection{Determination of the sampling locations}

The sampled points in this study were determined by the regular spatial sampling method with the use of GIS software. First, the grid was mapped on the City of Shiraz, and divided into 50 cells with each having an area of 25 $\mathrm{km}^{2}$, and four points per cell were spotted in each part of the units (based on the consistency of the studied variable). Then, 200 points were selected inside the study area in the City of Shiraz (Figure 1). By utilizing this method, an obvious illustration of the changes in the pattern of potential radon emissions based on the measurements of the 
buildings was obtained (28). According to the population in the City of Shiraz, one out of every 8,503 people was sampled. In studies that have been done usually every 18 to 39,000 people one home for radon monitor is selected (28). Fifteen detectors that were delivered to residents were missing when the detectors were collected, so those houses were excluded from the study. Overall, 10 redundant detectors were placed at the desired locations to verify the authenticity of the readings. Sampling from inside the residential buildings (bedroom and living room) was conducted in the winter $(29,30)$. Before the sampling was done, questionnaires were used to collect various parameters, such as the type of building, age of the building, the detectors' locations, types of materials, types of flooring and the number of floors where the sampling was done.

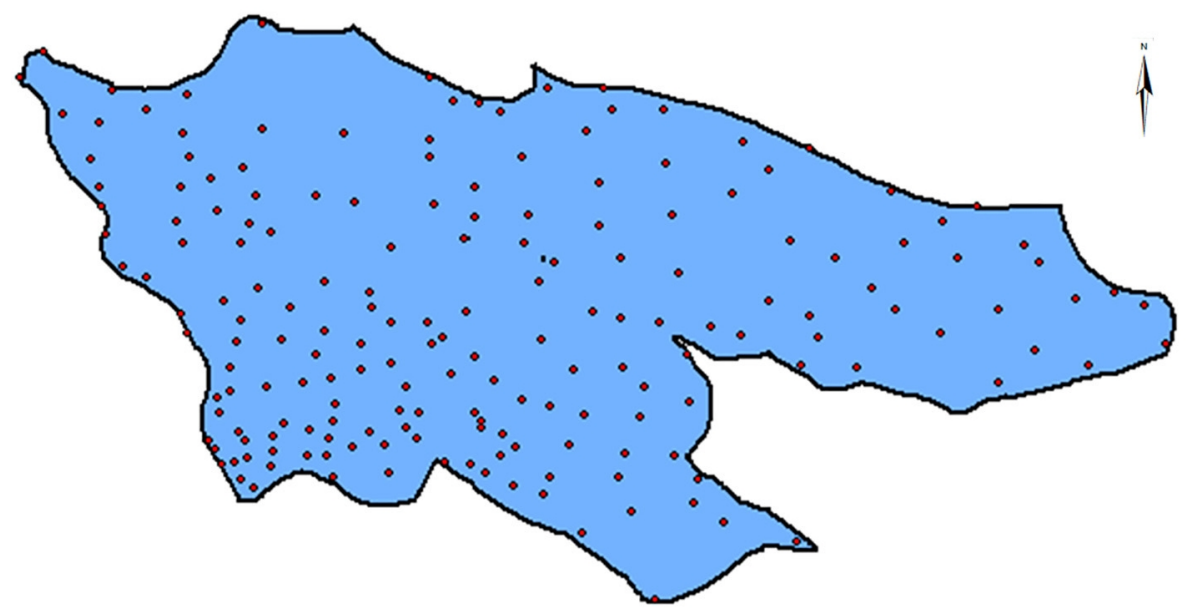

Figure 1. Sampling points in Shiraz to determine the concentration of radon gas in homes and public places

\subsection{Measurement of the concentration of radon gas}

The concentration of radon gas was measured with the Alpha Track method by a solid-state nuclear track detector (SSNTD) (CR-39 film). The alpha particles emitted from the radon gas leave some trails on the detectors, and they were made visible using electrochemical methods so they could be counted under the microscope (22, 31). All detectors were encoded after placement in the houses and were covered by aluminum foil to prevent external radiation. Next, by visiting the selected homes and buildings and after adequate briefing of the dwellers and gaining their consent and filling the questionnaires, the CR39 detectors were installed at the desirable locations based on the U.S. EPA's Protocol (32). After collection, the detectors were placed in a water bath that contained $6.25 \mathrm{M} \mathrm{NaOH}$ solution at $85^{\circ} \mathrm{C}$ for three hours. Then, they were rinsed with distilled water and dried. The alpha particle trails were read by an automatic counter, and the radon gas concentration was determined in Bq $/ \mathrm{m}^{3}$ by the device's software according to the sampling duration and calibration index (31). The data were analyzed using Excel software, IBMSPSS version 20 (IBMC Corp., Armonk, NY, USA), descriptive statistics, Kruskal-Wallis, and Mann-Whitney tests.

\section{Results}

\subsection{Concentration of radon gas in residential homes and public places in the City of Shiraz}

Table 1 shows that the mean and standard deviation (SD) of the concentration of radon gas in the sampled buildings in the City of Shiraz were $50.15 \pm 29.46 \mathrm{~Bq} / \mathrm{m}^{3}$. The concentration of radon gas in residential homes $(57.60 \pm 33.06$; Min: 250, Max: $17 \mathrm{~Bq} / \mathrm{m}^{3}$ ) was greater than it was in public places $\left(38.56 \pm 17.46\right.$; Min: $\left.86, \mathrm{Max}: 11 \mathrm{~Bq} / \mathrm{m}^{3}\right)$. The results of the Mann-Whitney test showed that the concentrations of radon gas in residential homes and public places in the City of Shiraz were different and that their mean difference was statistically significant $(p=0.000)$.

\subsection{Study of the concentration of radon gas based on the age of the building}

Table 1 indicates that the concentration of radon gas in old buildings in the city of Shiraz was greater than it was in new buildings. The results of the Mann-Whitney Statistical Test indicated that, despite the mean difference of radon gas concentration between the old and new buildings in the city of Shiraz, this difference was not statistically significant $(\mathrm{p}=0.131)$. A possible reason may have been the small number of samples that we obtained. 
http://www.ephysician.ir

Table 1. Comparison of the concentration of radon gas (in $\mathrm{Bq} / \mathrm{m}^{3}$ ) in residential homes and public places in the City of Shiraz

\begin{tabular}{|l|l|l|l|l|l|l|}
\hline Variables & $\mathrm{n}$ & Mean & SD & Minimum & Maximum \\
\hline \multirow{2}{*}{ Type of Building } & Residential & 112 & 57.6 & 33.06 & 17 & 250 \\
\cline { 2 - 7 } & Public Place & 73 & 38.56 & 17.46 & 11 & 86 \\
\hline \multirow{3}{*}{ Age of Building } & Newly-Built & 97 & 47 & 24.91 & 14 & 170 \\
\cline { 2 - 7 } & Old & 88 & 53.6 & 33.54 & 11 & 250 \\
\hline Places Sampled & Bedroom & 107 & 54.94 & 31 & 16 & 250 \\
\cline { 2 - 7 } & Living Room & 78 & 43.5 & 25.93 & 11 & 179 \\
\hline \multirow{3}{*}{ Floors in the Building } & Ground Floor & 145 & 49.63 & 31.07 & 11 & 250 \\
\cline { 2 - 7 } & $2^{\text {nd } \text { Floor and up }}$ & 40 & 42.35 & 17.78 & 16 & 123 \\
\hline \multirow{3}{*}{ Material used for the Building } & Brick & 172 & 49.65 & 25.97 & 11 & 179 \\
\cline { 2 - 7 } & Cement Block & 13 & 57.41 & 62.42 & 23 & 250 \\
\hline Flooring in the Building & Stone & 14 & 43 & 24.6 & 11 & 95 \\
\cline { 2 - 7 } & Ceramic & 66 & 59.19 & 39.4 & 14 & 250 \\
\cline { 2 - 6 } & Mosaic & 105 & 45.35 & 20.2 & 15 & 112 \\
\hline
\end{tabular}

\subsection{Study of the concentration of radon gas based on the location of the detector}

Table 1 indicates that the concentration of radon gas in the bedroom was greater than the concentration in the living room. The results of the Mann-Whitney Statistical Test indicated that the concentrations of radon gas were different between the bedroom and the living room and that their difference was statistically significant $(p=0.001)$.

\subsection{Study of the concentration of radon gas based on the floors that were sampled}

Table 1 indicates that the mean concentration and SD of radon gas at the ground floor were greater than they were on the second floor and above. The results of the Mann-Whitney Statistical Test showed that the concentration of the radon gas differed depending on the floor that was sampled (i.e., the ground floor and others) and that it was statistically significant $(\mathrm{p}=0.05)$.

\subsection{Study of the concentration of radon gas based on the materials used in building construction}

Table 1 indicates that the average concentration and SD of radon gas in buildings that used blocks and cement were greater than they were in buildings that used brick and cement. The results of the Mann-Whitney Statistical Test showed that the concentrations of radon gas with respect to the type of materials (brick and cement, or block and cement) were not different, and they were not statistically significant $(p=0.525)$. This means that the type of materials used had no effect on the concentration of radon gas. However, as Table 1 shows, in this study, there were far fewer buildings constructed with block and cement (i.e., 13) than buildings constructed with brick and cement (i.e., 172). Perhaps if the number of samples were greater, the difference in the concentrations might become statistically significant.

\subsection{Study of the concentration of radon gas in residential houses and public places in the City of Shiraz according to the type of flooring}

Table 1 indicates that the maximum concentration of radon gas occurred in the buildings with ceramic flooring. The results of the Kruskal-Wallis Statistical Test indicated that the concentrations of radon gas in homes and public places in the City of Shiraz were different with respect to the type of flooring (mosaic, ceramic, stone) and that the differences were statistically significant $(\mathrm{p}=0.038)$.

\subsection{Calculation of the annual effective dose of radon gas in residential houses in the City of Shiraz}

According to the results obtained from the mean concentration of radon gas in the residential units, the annual mean dosage (in $\mathrm{mSv}$ per year) by the residents in the City of Shiraz due to indoor radon was determined using the UNSCEAR-2000 model (33):

$\mathrm{E}=\mathrm{C} \times \mathrm{F} \times \mathrm{H} \times \mathrm{T} \times \mathrm{D}$,

where $\mathrm{C}$ is the indoor concentration of radon in $\mathrm{Bq} / \mathrm{m}^{3}$, and the value of $\mathrm{C}$ in residential homes in the City of Shiraz was $57.6 \pm 33.06)$; $\mathrm{F}$ is the adjustment factor $(0.4$ for indoor measurements); $\mathrm{H}$ is the occupancy factor ( 0.8 for indoor measurements); $\mathrm{T}$ is the number of hours in a year (8760 hours for one year of residence in the house); and $\mathrm{D}$ is the dose conversion factor for the whole body dose calculation $\left(0.9 \mathrm{nSv}\right.$ per $\left.\mathrm{Bq} \mathrm{m}^{-3} \mathrm{~h}^{-1}\right)$ (22). According to the 
results obtained, the average annual effective dose of radon gas in residential homes for the residents in the City of Shiraz was $1.45 \mathrm{mSv} / \mathrm{y}$.

\section{Discussion}

In recent years, natural exposure to radon gas and its decay products in residential homes has become a global problem and has raised concerns as a result of their negative impact on human health. The average concentration of radon gas in residential homes in the City of Shiraz was $57.6 \pm 33.06 \mathrm{~Bq} / \mathrm{m}^{3}$, and the effective annual dose for an individual was $1.45 \mathrm{mSv} / \mathrm{y}$, which is lower than the permissible threshold. A comparison of the results in the present study and the results of other studies on the measurement of the concentration of radon gas is given in Table 2. The International Commission on Radiological Protection (ICRP) has suggested an amount of $300 \mathrm{~Bq} / \mathrm{m}^{3}$ (equivalent to $10 \mathrm{mSv}$ per year) as the reference level (34). Therefore, taking the economic and social conditions into account, the concentration of radon gas should not exceed this figure, and, according to Table 1, none of the samples taken in the City of Shiraz was above $250 \mathrm{~Bq} / \mathrm{m}^{3}$. Since the world's average radon concentration in residential homes has been estimated at $39 \mathrm{~Bq} / \mathrm{m}^{3}(6)$, the average concentration of radon gas in the City of Shiraz was greater than the global average. According to WHO's studies, there is no safe threshold that can eliminate the risk, and the results of the shared analysis of data on radon studies in residential homes in Europe, North America, and China show that the risk of lung cancer increases almost linearly with prolonged radon exposure. The studies show that, when the concentration of radon in the house is nearly $21 \mathrm{~Bq} / \mathrm{m}^{3}$, the risk of lung cancer for a smoker is about 30 times more than for a non-smoker $(6,25)$. Since the results of the present study indicated that 49 out of the 185 households that were studied had at least one person smoking cigarettes, the risk of lung cancer will increase, and it is necessary to educate and inform the people through the responsible organizations in the City of Shiraz. The average concentration of radon gas in this study was less than the average reported by Haddad (24), which was a study conducted in Shiraz between 2009 and 2010 on 131 homes in two consecutive six-month periods. The average concentration of radon gas was reported as $94 \pm 52 \mathrm{~Bq} / \mathrm{m}^{3}$. The difference in the concentration of radon gas was due to the difference between the sampled homes, the number of samples, as well as the sampled floors. In the Haddad study, almost $61 \%$ of the samples were taken from the basements and ground floors, and, naturally, these floors contain a higher concentration of radon gas. The U.S. EPA has proposed the permissible threshold of $400 \mathrm{~Bq} / \mathrm{m}^{3}$ for workplace and public places (34). However, according to the results of the present study, the average concentration of radon gas in all measured samples was lower than this value. The average concentration of this gas reported in various cities were quite different, e.g., Tehran was $68 \pm 84$, Babolsar was $35 \pm 83$, Gonabad was $79 \pm 3$, and Yazd was $137.36 \pm 149.5 \mathrm{~Bq} / \mathrm{m}^{3}(21,22)$. Comparing the results of this study with the concentration limit of the radon gas proposed by WHO $\left(100 \mathrm{~Bq} / \mathrm{m}^{3}\right)$ (6) indicated that the concentrations of radon gas in indoor air for $94.6 \%$ of the samples were in the lower range, but $5.4 \%$ of the samples taken from the residential homes and public places in the City of Shiraz were in the higher range of the limit set by WHO. Therefore, by boosting the allocations and increasing the level of public awareness concerning the hazards of radon gas, it is recommended that more precise studies be conducted to determine the parameters that influence the penetration of radon gas into the buildings. Therefore, due to the fact that radon gas has been proven to be the second cause of lung cancer around the world, it is necessary to take relevant measures to reduce radon in homes that have radon concentrations higher than the world standard. The results of a study conducted by Molavi in 2010 on 150 apartments in Mashhad showed that, in $94.7 \%$ of the apartments, the radon concentration was less than $100 \mathrm{~Bq} / \mathrm{m}^{3}$, but in $5.3 \%$ of the apartments, it was higher than this amount (35).

Table 2. Comparison of the results of this study with those of other studies on the measurement of radon gas concentrations (in $\mathrm{Bq} / \mathrm{m}^{3}$ )

\begin{tabular}{|l|l|l|l|}
\hline Reference & Location & Technique Used & Mean \pm SD \\
\hline Hadadi (33) & 196 houses in Tabriz & CR-39 & $39 \pm 25$ \\
\hline Yousefi et al. (30) & 218 houses in Gorgan & CR-39 & $43.99 \pm 37.8$ \\
\hline Sohrabi and Babapouran (34) & 500 houses in 12 regions of Ramsar & polycarbonate detectors & $566 \pm 677$ \\
\hline This study & 185 houses and public places in Shiraz & CR-39 & $50.11 \pm 29.66$ \\
\hline
\end{tabular}

\subsection{Comparison of the concentration of radon gas in residential homes and public places in the City of Shiraz with U.S. EPA's standards}

According to the U.S. EPA's standard, in the event that the concentration of radon gas in the air inside the residential homes is less than 74,74 to 148 , and above $148 \mathrm{~Bq} / \mathrm{m}^{3}$, it should be designated as safe range, low-risk range, and a dangerous range, respectively (36). The concentrations of radon gas in the indoor air of $81.08 \%$ of the collected samples were in the safe range in which the average and SD of the radon gas concentration was $40.2 \pm$ 
$14.36 \mathrm{~Bq} / \mathrm{m}^{3}$ and the effective annual dose was $2.11 \mathrm{mSv}$. However, $16.75 \%$ were in the low-risk range in which the average and SD of the radon gas concentration were $85.06 \pm 14.56 \mathrm{~Bq} / \mathrm{m}^{3}$ and the effective annual dose was 2.11 $\mathrm{mSv}$, and $2.16 \%$ were in the dangerous range in which the average and SD of the radon gas concentration were 192 $\pm 38.92 \mathrm{~Bq} / \mathrm{m}^{3}$ and the effective annual dose was $4.84 \mathrm{mSv}$. On average, in the U.S., one out of every 15 residential homes (approximately $6.6 \%$ of the total homes) and in some parts of the country, one out of every 3 homes has radon gas concentrations higher than national reference $\left(148 \mathrm{~Bq} / \mathrm{m}^{3}\right)(6)$. The average annual dose received by every person from natural sources is $2.4 \mathrm{mSv}$, of which $1.2 \mathrm{mSv}$ corresponds to radon gas alone (2). According to the results, in 19\% of the homes sampled in Shiraz, the average annual dosage was higher than the permissible threshold of radon gas, and it was much lower than the annual individual effective received dose in the Ramsar area, which is 2.48-71.74 mSv (21). However, it is noteworthy that parts of the city of Ramsar are situated in northern Iran, and they have the highest rate of natural radioactivity in the world as a result of the hot springs that contain radium 226 (31). The studies by Yousefi et al. (31) and Ranjbar et al. (37) showed that the concentrations of radon gas in nearly $3 \%$ of the residential homes in the cities of Gorgan and Rafsanjan were higher than the amount of the proposed U.S. EPA standard. The Danish Ministry of Health has announced that $4.6 \%$ of the homes have radon levels in excess of the standard level (38). In $50 \%$ of the American residential homes, the radon concentration is $148 \mathrm{~Bq} / \mathrm{m}^{3}(36)$.

\subsection{Study of the concentration of radon gas based on the age of the building}

The levels of radon in buildings change substantially with the passage of time and the aging of the used materials (22). The average annual effective doses resulting from the radon gas in old and new buildings in the City of Shiraz were 1.35 and $1.18 \mathrm{mSv}$ per year, respectively. The dose received in the old buildings is higher than the doses received in the new buildings that are attributable to radon gas $(1.25 \mathrm{mSv}$ per year). The International Commission of Radiation Protection (ICRP) has proposed a maximum acceptable concentration for the newly-built homes as 100 $\mathrm{Bq} / \mathrm{m}^{3}$ (39). The concentrations of radon gas in the newly-built buildings in the City of Shiraz were less than the maximum acceptable concentration set by the ICRP. A study by Haddad (22) in the City of Yazd suggested that the concentration of radon gas in old buildings is higher than that in new buildings.

\subsection{Study of the concentration of radon gas based on the placement of the detector}

Measurement of the concentration of radon gas should be made at a point in the building that is regularly used by the residents and located at the lowest level, e.g., bedroom, living room, reception room, or the children's play room (32). In this study, nearly $60 \%$ of the detectors were installed in the bedroom. The results of the present study indicated that the concentration of radon gas in the bedroom was higher than the concentration in the living room. The results of the study by Yousefi et al. (31) in the City of Gorgan showed that the average and SD of the concentration of radon gas in the bedroom were $48.04 \pm 40.39$ while they were $39.94 \pm 35.22 \mathrm{~Bq} / \mathrm{m}^{3}$ in the living room. Also, the results of a study by Denman \& Rafigh using Cr-39 detectors in residential homes showed that the concentration of radon gas in the bedroom was higher than the concentration in the living room, which matches the results of the present study $(40,41)$.

\subsection{Study of the concentration of radon gas based on the floor that was sampled}

The U.S. EPA has proposed that, for all buildings, the amounts of radon gas must be measured on the floors below the third floor (32). The results show that the average annual effective doses of radon for residents living on the ground floor and above the first floor in the City of Shiraz were 1.25 and $1.06 \mathrm{mSv}$ per year, respectively. Therefore, the dose received at the ground floor is equal to the dose intake attributable to radon gas (1.25 $\mathrm{mSv}$ per year), and it is less than that for floors above the first floor. Radon gas has a density of $9.73 \mathrm{~g} / \mathrm{l}$, so it is a heavy gas compared to air, and it tends to move downwards. So, the concentrations of radon gas in the basement and on the ground floor are higher than the concentrations on other floors (39). Therefore, as one moves to the higher floors, the concentrations of radon gas are reduced significantly, and, consequently, the dosage received by the residents of such buildings are reduced. The reason may be due to the distance from the Earth's surface and the origin of the radon gas $(30,33)$. The results of the study by Yousefi et al. (31) showed that the average background doses of radon gas in residential homes for the residents in the City of Gorgan in the buildings with a ground floor, a single floor and over 1 floor, were $1.1,0.99$, and $0.34 \mathrm{mSv} / \mathrm{y}$ respectively. The results of a study by Haddadi in the city of Tabriz indicated that the concentration of radon gas in the basement was $48 \pm 40$, on the first floor it was $44 \pm 20$, on the second floor it was $43 \pm 28$, while on the third floor it was $25 \pm 12 \mathrm{~Bq} / \mathrm{m}^{3}$. The amount of gas in the indoor air of the homes located on the third floor is significantly different than the amount in the basement of the building. The basement of the buildings contained the highest concentration of the gas (39). 


\subsection{Study of the concentration of radon gas based on the construction materials}

People inside their homes are protected from too much radiation of radioactive materials that are emitted from the outside environment.But the construction materials are an important source of radon inside these places, and, among them, the materials that were extracted from the Earth are the most important $(23,42)$. The annual effective dosages in homes that were built with bricks and cement or with blocks and cement were 1.25 and $1.45 \mathrm{mSv} / \mathrm{y}$, respectively. Therefore, the dosage received from buildings that used block and cement was more than the dose attributable to radon gas. The construction materials, such as sand, rock, and wood, contain of radionuclides including particularly Ra-226, Th-232 and K-40. Among construction materials, concrete has the highest potential for releasing radon. Therefore, the dose radiated to people residing in the buildings has been increased rather than decreased (42). The building materials, when compared with the soil and underground water, are considered small sources of radon gas unless they show high concentrations of radium. Overall, the building materials can increase the rate of radon gas emission by $30-50 \%$ (6). The results of the study by Haddadi in the City of Tabriz indicated that the concentration of radon gas in concrete buildings was $16 \pm 25$, in brick buildings it was $29 \pm 16$, while, in clay building materials, it was $70 \pm 40 \mathrm{~Bq} / \mathrm{m}^{3}$ (39). Compared to concrete, bricks emit less radon (6). Due to the heavy weight of materials used in the construction of buildings, particularly for materials containing high levels of radium, the amount of radon gas emissions relative to the soil is of secondary importance. Although the concentration of radium 226 in various materials, such as tile, cement, concrete, and brick, is in the range of $200-100 \mathrm{~Bq} / \mathrm{kg}$, there is very little impact on increasing the concentration of radon in the indoor air because the amount of radon 222 is very low. Also, despite the low radium concentrations in wood $(\sim 1 \mathrm{~Bq} / \mathrm{kg})$, any radon in it easily can be emitted because of the existence of so many pores (6).

\subsection{Study of the concentration of radon gas in residential homes and public places in the city of Shiraz based on the type of flooring}

Table 1 indicates that the concentration of radon gas in the buildings with ceramic flooring had the maximum value compared to other types of flooring. The results of a study by Majed et al. (43) showed that the materials used in the manufacture of ceramic materials are the main sources of radon in closed spaces. The radon emissions of the industrial ceramics manufactured in 13 Egyptian plants were $668 \pm 68 \mathrm{~Bq} / \mathrm{m}^{3}$. The results of a study by Yousefi et al. in the City of Gorgan showed that the average concentration of radon gas in the buildings with ceramic flooring and mosaic floorings were 34 and $56.76 \mathrm{~Bq} / \mathrm{m}^{3}$, respectively (31).

\section{Conclusions}

The average concentration of radon gas in residential homes in the City of Shiraz was $57.6 \pm 33.06 \mathrm{~Bq} / \mathrm{m}^{3}$, and the effective annual dosage an individual received was $1.45 \mathrm{mSv} / \mathrm{y}$, which was lower than the permissible threshold. The average concentration of radon gas in the City of Shiraz was higher than the global average. It is necessary to increase the level of public awareness concerning the hazards of radon gas. Also, for the new buildings in Shiraz, the construction authorities should use reasonable approaches to minimize the presence of radon, such as building insulation, installation of ventilation systems, and the use of materials with low radon emissions. It is necessary to conduct further studies in the field of regional geology, and the sources that release radon in these areas should be accurately identified to minimize the amount of exposure of the residents.

\section{Acknowledgments:}

This paper was derived from the research proposal coded 21333, which was approved by the Center for Air Pollution Research (CAPR), Institute for Environmental Research (IER), Tehran University of Medical Sciences. We wish to thank the staff members of the Institute for Environmental Research (IER) and Shiraz University of Medical Sciences for their financial support to conduct this work. We thank Farshad Karimnejad who helped us in data collection of this study.

\section{Conflict of Interest:}

There is no conflict of interest to be declared.

\section{Authors' contributions:}

All authors contributed to this project and article equally. All authors read and approved the final manuscript.

\section{References:}

1) Kant K, Upadhyay SB, Sharma GS, Chakarvarti SK. Measurement of inhalation dose due to radon and its progeny in an oil refinery and its dwellings. Iran J Radiat Res. 2004; 1(4): 181-6. 
2) UNSCAR. Sources, Effects And Risks Of Ionizing Radiation. 2015.

3) Mostafa AMA, Yamazawa H, Uosif MAM, Moriizumi J. Seasonal behavior of radon decay products in indoor air and resulting radiation dose to human respiratory tract. Journal of Radiation Research and Applied Sciences. 2015; 8(1): 142-7. doi: 10.1016/j.jrras.2014.12.007.

4) EPA Assessment of Risks from Radon in Homes. Office of Radiation and Indoor Air United States Environmental Protection Agency, Washington, DC; 2003.

5) World Health Organization ROfE. Guidelines for indoor air quality: selected pollutants 2010.

6) Zeeb H, Shannoun F. WHO handbook in indoor radon: a public health perspective. Geneva, Switzerland: World Health Organization (WHO); 2009.

7) Appleton JD. Radon in air and water, In: Selinus OA, BJ, Smedley, P, editor, Essentials of Medical Geology. Netherlands: Springer. 2013; 239-77.

8) Pressyanov D, Dimitrov D, Dimitrova I. Energy-efficient reconstructions and indoor radon: the impact assessed by CDs/DVDs. J Environ Radioact. 2015; 143: 76-9. doi: 10.1016/j.jenvrad.2015.02.016. PMID: 25748339.

9) Casey JA, Ogburn, EL, Rasmussen SG, Irving JK, Pollak J, Locke PA, et al. Predictors of Indoor Radon Concentrations in Pennsylvania, 1989-2013. Environ Health Perspect. 2015; 123: 1130-7. doi: 10.1289/ehp.1409014. PMID: 25856050, PMCID: PMC25856050.

10) Kendall GM, Smith TJ. Doses to organs and tissues from radon and its decay products. J Radiol Prot. 2002; 22(4): 389. doi: 10.1088/0952-4746/22/4/304. PMID: 12546226.

11) William W, Nazaroff AVN. Radon and Its Decay Products in Indoor Air 1 ed: Wiley-Interscience; 1988.

12) Arvela H. Experiences in radon-safe building in Finland. Sci Total Environ. 2001; 272(1-3): 169-74. doi: 10.1016/S0048-9697(01)00688. PMID: 11379905.

13) Anastasiou T, Tsertos H, Christofides S, Christodoulides G. Indoor radon (222Rn) concentration measurements in Cyprus using high-sensitivity portable detectors. J Environ Radioact. 2003; 68(2): 159-69. doi: 10.1016/S0265-931X(03)00052-3. PMID: 12763326.

14) Marenny AM, Shinkarev SM, Penezev AV, Savkin MN, Hoshi M. Assessment of exposure to the population of Russia from radon. International Congress Series. 2005; 1276: 352-3. doi: 10.1016/j.ics.2004.10.019.

15) Lehmann R, Kemski J, Siehl A, Stegemann R, Valdivia-Manchego M. The regional distribution of indoor radon concentration in Germany. International Congress Series. 2002; 1225: 55-61. doi: 10.1016/S05315131(01)00544-1.

16) Sainz C, Dinu A, Dicu T, Szacsvai K, Cosma C, Quindós LS. Comparative risk assessment of residential radon exposures in two radon-prone areas, Stei (Romania) and Torrelodones (Spain). Sci Total Environ. 2009; 407(15): 4452-60. doi: 10.1016/j.scitotenv.2009.04.033. PMID: 19428051.

17) Nhan DD, Fernando CP, Thu Ha NT, Long NQ, Thuan DD, Fonseca H. Radon (222Rn) concentration in indoor air near the coal mining area of Nui Beo, North of Vietnam. J Environ Radioact. 2012; 110: 98-103. doi: 10.1016/j.jenvrad.2012.02.008. PMID: 22445878 .

18) Pereira CE, Vaidyan VK, Chougaonkar MP, Mayya YS, Sahoo BK, Jojo PJ. Indoor radon and thoron levels in Neendakara and Chavara regions of southern coastal Kerala, India. Radiat Prot Dosimetry. 2012; 150(3): 385-90. doi: 10.1093/rpd/ncr399. PMID: 22080470.

19) Celik N, Cevik U, Celik A, Kucukomeroglu B. Determination of indoor radon and soil radioactivity levels in Giresun, Turkey. J Environ Radioact. 2008; 99(8): 1349-54. doi: 10.1016/j.jenvrad.2008.04.010. PMID: 18501486.

20) Al-Saleh FS. Measurements of indoor gamma radiation and radon concentrations in dwellings of Riyadh city, Saudi Arabia. Appl Radiat Isot. 2007; 65(7): 843-8. doi: 10.1016/j.apradiso.2007.01.021. PMID: 17391973.

21) Pirsaheb M, Najafi F, Khosravi T, Hemati L. A systematic review of radon investigations related to public exposure in iran. Iran Red Crescent Med J. 2013; 15(11): 10204. doi: 10.5812/ircmj.10204. PMID: 24719680, PMCID: PMC3971772.

22) Hadad K, Mokhtari J. Indoor radon variations in central Iran and its geostatistical map. Atmospheric Environment. 2015; 102: 220-7. doi: 10.1016/j.atmosenv.2014.12.013.

23) Rezazadeh AN. Radon concentrations in public water supplies in Tehran and evaluation of radiation dose. Iranian Journal of Radiation Research. 2005; 3(2): 79-83.

24) Hadad K, Hakimdavoud MR, Hashemi Tilehnoee M. Indoor radon survey in Shiraz-Iran using developed passive measurement method. Iran J Radiat Res. 2011; 9(3): 175-82. 
25) Hazar N, Karbakhsh M, Yunesian M, Nedjat S, Naddafi K. Perceived risk of exposure to indoor residential radon and its relationship to willingness to test among health care providers in Tehran. J Environ Health Sci Eng. 2014; 12(1): 118. doi: 10.1186/s40201-014-0118-2. PMID: 25426296 , PMCID: PMC4243733.

26) Shojaee F, Aryamanesh M, Akashe B. Study of Active Faults by using Remote Sensing Data Processing and Morphotectonics Indicators- A case Shiraz township. Journal of the Earth. 2012; 6(22): 133-44.

27) Iran SCo. Atlas of Selected Results of the 2011 National Population and Housing Census: Statistical Centre of Iran; 2011. Available from: http://www.amar.org.ir/Portals/1/Iran/Atlas_Census_2011.pdf.

28) Miles JC, Appleton JD. Mapping variation in radon potential both between and within geological units. J Radiol Prot. 2005; 25(3): 257-76. doi: 10.1088/0952-4746/25/3/003. PMID: 16286689.

29) Gillmore GK, Jabarivasal N. A reconnaissance study of radon concentrations in Hamadan city, Iran. Nat Hazards Earth Syst Sci. 2010; 10(4): 857-63. doi: 10.5194/nhess-10-857-2010.

30) Rahimi A, Nikpour B. Measurement of Radon Concentration of Air Samples and Estimating Radiation Dose from Radon in SARI Province. Universal Journal of Public Health. 2013; 1: 26-31. doi: 10.13189/ujph.2013.010203.

31) Yousefi Z, Naddafi K, Mohamadpur RA, Zazouli MA, Koushki Z. Indoor Radon Concentration in Gorgan Dwellings Using CR-39 Detector. Journal of Mazandaran University of Medical Sciences. 2014; 24(113): 2-10.

32) Agency USEP. Indoor Radon and Radon Decay Product Measurements in Homes. 1992.

33) Nations USU. Effects of Ionizing Radiation. New York 2000 p. 453-87.

34) Espinosa G, Gammage R. An Indoor Radon Survey in Three Different Climate Regions in Mexico, and the Influence of Climate in the Obtained Values. Journal of Environmental Protection. 2011; 2(9): 1143-8. doi: 10.4236/jep.2011.29133.

35) Mowlavi AA, Fornasier MR, Binesh AR, Denaro MD. Indoor radon measurement and effective dose assessment of 150 apartments in Mashhad, Iran. Environ Monit Assess. 2012; 184. doi: 10.1007/s10661011-2022. PMID: 21625925.

36) Kitto ME, Green JG. Mapping the indoor radon potential in New York at the township level. Atmospheric Environment. 2008; 42(34): 8007-14. doi: 10.1016/j.atmosenv.2008.06.039.

37) Askari HR, Rahimi M, Negarestani A. The investigation and measurement of the radon gas working level inside buildings in Rafsanjan. Int J Low Radiat. 2008; 5(2): 98-103. doi: 10.1504/IJLR.2008.019914.

38) Petersen ML, Larsen T. Cost-benefit analyses of radon mitigation projects. J Environ Manage. 2006; 81(1): 19-26. doi: 10.1016/j.jenvman.2005.10.005. PMID: 16616412.

39) Haddadi G. Assessment of Radon level in dwellings of Tabriz. Journal of Fasa University of Medical Sciences. 2011; 1(1): 13-9.

40) Denman AR, Groves-Kirkby NP, Groves-Kirkby CJ, Crockett RG, Phillips PS, Woolridge AC. Health implications of radon distribution in living rooms and bedrooms in UK dwellings-a case study in Northamptonshire. Environ Int. 2007; 33(8): 999-1011. doi: 10.1016/j.envint.2007.01.011. PMID: 17399788.

41) Rafique M, Rahman S, Rahman SU, Jabeen S, Shahzad MI, Rathore MH, et al. Indoor radon concentration measurement in the dwellings of district Poonch (Azad Kashmir), Pakistan. Radiat Prot Dosimetry. 2010; 138(2): 158-65. doi: 10.1093/rpd/ncp203. PMID: 19828719.

42) Henriksen T MH. Radiation and Health: Taylor \& Francis; 2011.

43) Maged AF, Ismail LZ, Moussa NLA. Environmental risk assessment of radon from ceramic tiles. Radioprotection. 2012; 47(3): 403-11. doi: 10.1051/radiopro/2012011. 